\title{
Uji Daya Hasil Biji Terhadap 10 Galur Mutan Harapan Sorgum di Beberapa Lokasi
}

\section{Yield Evaluation Trials of 10 Promising Mutant Lines Sorgum in Some Locations}

\author{
Sihono dan Wijaya M. Indriatama \\ Pusat Aplikasi Isotop dan Radiasi, BATAN \\ Jalan Lebak Bulus Raya No. 49 Jakarta 12440 \\ Email : sihono@batan.go.id
}

\begin{abstract}
ABSTRAK
Sorgum berpotensi besar dan prospektif untuk dibudidayakan dan dikembangkan, seiring dengan semakin meningkatnya jumlah kebutuhan pangan di Indonesia. Pemuliaan sorgum dengan teknik mutasi radiasi telah dilakukan di Pusat Aplikasi Isotop dan Radiasi (PAIR), Badan Tenaga Nuklir Nasional (BATAN). Tujuan pemuliaan adalah untuk memperbaiki hasil dan kualitas sebagai pangan. Materi induk yang digunakan adalah galur mutan $\mathrm{Zh}-30$ (varietas Pahat) berasal dari hasil penelitian BATAN diradiasi sinar gamma menggunakan dosis $300 \mathrm{~Gy}$. Kegiatan seleksi menggunakan metode pedigree, dimulai pada generasi $\mathbf{M}_{2}$ dan $\mathbf{M}_{3}$, yaitu dengan memilih tanaman yang memiliki sifat-sifat agronomi lebih baik dibanding induknya, kemudian dilanjutkan pada generasi berikutnya. Sejumlah 10 galur mutan harapan yaitu PATIR-1, PATIR-4, PATIR-12, PATIR-13, PATIR-15, PATIR-61, PATIR-71, PATIR-81, PATIR91 dan PATIR-101 dievaluasi pada uji adaptasi multilokasi. Metode percobaan menggunakan rancangan acak kelompok dengan 3 ulangan. Tiga varietas sorgum yaitu Pahat, Kawali dan Mandau dimasukkan sebagai tanaman kontrol. Parameter data dilakukan terdiri dari beberapa karakter agronomi termasuk hasil biji dianalisis menggunakan ANOVA software komputer metode SAS versi 9.1. Hasil menunjukkan bahwa galur mutan PATIR-4 memiliki hasil biji tertinggi 6,43 t/ha dan diikuti galur PATIR-1 yaitu 6,15 t/ha berbeda nyata secara uji BNT 5\% dibandingkan ketiga tanaman kontrol Zh-30 (induk), Kawali dan varietas Mandau (kontrol nasional) berturut-turut hanya 4,26, 5,26 dan 5,43 t/ha.
\end{abstract}

Kata Kunci: pemuliaan mutasi, sorgum, galur mutan, uji adaptasi.

\begin{abstract}
Sorghum has big potential and prospective to be growing and developed, along with the increasing number of food needs in Indonesia. Mutation breeding of sorghum with irradiation techniques has been held at the Center for Isotope and Radiation Application (CIRA), National Nuclear Energy Agency (BATAN). The objective of research was to improve yield and quality of sorghum as food. The used material parent was Zh-30 mutant line (Pahat variety) resulted from gamma rays irradiation using 300 Gy dose. The selection activities used pedigree method, starting on the $\mathrm{M}_{2}$ and $\mathrm{M}_{3}$ generation. It was done by choosing plants that have agronomic characters better than the parent, than followed in next successive generations. A number of 10 promising mutant lines (PATIR-1, PATIR-4, PATIR-12, PATIR-13, PATIR1 5, PATIR-61, PATIR-71, PATIR-81, PATIR-91 and PATIR-101) were evaluated on the multi-location trials. The experimental method used randomized complete block design with 3 replications. Three sorghum varieties namely Pahat (parent), Kawali and Mandau (national varieties) were included as control varieties. Data measurements were collected for several agronomic characters including grain yield, analyzed by using ANOVA softwares SAS method of versi 9.1. The results showed that the PATIR-4 mutant line had the highest grain yield of $6.43 \mathrm{t} / \mathrm{ha}$ and followed by PATIR-1 mutant line of $6.15 \mathrm{t} / \mathrm{ha}$. They were significantly different compared to the three control varieties (Zh-30, Kawali and Mandau varieties).
\end{abstract}

Keywords : mutation breeding, sorghum, mutant lines, adaptation test. 


\section{PENDAHULUAN}

Sorgum sebagai pangan global menempati urutan ke-5 setelah gandum, jagung, padi dan barley [1]. Sorgum (Sorghum bicolor L) termasuk tanaman serealia (biji-bijian) multiguna, biji untuk pangan dan industri olahan (kue, roti, mie dll), batangnya diperas menghasilkan air nira sebagai bahan bioenergi nabati serta hijauan daun dan batang dapat dimanfaatkan sebagai pakan ternak ruminansia.

Di Indonesia sebenarnya sudah lama dikenal dan ditanam oleh masyarakat petani, biasanya ditanam dengan tumpang sari atau sebagai tanaman sela, bijinya digunakan sebagai pangan alternatif dan hijauan daun serta batang digunakan untuk ternak. Keunggulan sorgum adalah bisa di ratoon dan dapat tumbuh dilahanlahan kering dan masam yang banyak dijumpai di Indonesia dimana pemanfaatan lahan sampai saat ini belum optimal [2].

Sorgum bukan tanaman asli Indonesia, oleh karena itu keragaman genetik yang ada masih sangat rendah maka kegiatan pemuliaan tanaman sangat diperlukan. Di Pusat Aplikasi Isotop dan Radiasi, Badan Tenaga Nuklir Nasional (PAIRBATAN) kegiatan penelitian pemuliaan tanaman menggunakan iptek nuklir yaitu dengan irradiasi sinar gamma. Penelitian pemuliaan tanaman menggunakan teknik mutasi radiasi telah menghasilkan dan melepas beberapa varietas baru diantaranya kedelai (varietas Muria, Tengger, Meratus, Rajabasa, Mitrani, Mutiara-1, 2 dan 3 serta Gamma Sugen 1 dan 2), kacang hijau (varietas Camar dan Muri), kapas (varietas Kharisma), gandum tropis (varietas Ganesha), sorgum (varietas Pahat, Samurai 1 dan 2) dan kacang tanah (varietas Katantan). Untuk padi mulai dari tahun 1982 telah dihasilkan 22 varietas yaitu dari Atomita-1 sampai dengan 2017, telah dihasilkan varietas baru yaitu Mustaban [3].

Kegiatan penelitian pemuliaan tanaman sorgum dilakukan menggunakan radiasi sinar gamma, dengan tujuan untuk memperbaiki beberapa sifat tanaman menjadi lebih unggul dibandingkan induknya. Dosis optimal sinar gamma telah diperoleh berada pada kisaran 20-50 kRad atau 200-500 Gy [4, 5]. Seleksi dilakukan menggunakan metode pedigree, memilih tanaman yang memiliki sifat-sifat agronomi unggul dimulai pada generasi $\mathrm{M}_{2}$, terfokus pada populasi tanaman dalam kisaran dosis optimal tersebut. Kegiatan pemuliaan sorgum dengan teknik mutasi menggunakan radiasi sinar gamma bersumber dari Cobalt-60. Benih sorgum galur mutan $\mathrm{Zh}-30$ (varietas Pahat) diradiasi dengan dosis $300 \mathrm{~Gy}$. Setelah melalui tahapan-tahapan seleksi, secara agronomi telah diperoleh 10 galur mutan harapan sorgum. Galur-galur tersebut dilakukan uji adaptasi dibeberapa lokasi, sebagai salah satu prasyarat untuk diajukan dan dilepas menjadi varietas unggul baru.Tujuan penelitian ini adalah untuk memperoleh informasi hasil biji dari beberapa lokasi pengujian terhadap10 galur mutan harapan sorgum.

\section{BAHAN DAN METODE}

Bahan penelitian yang digunakan adalah 10 nomor galur mutan harapan sorgum hasil penelitian sebelumnya yaitu galur mutan PATIR1, PATIR-4, PATIR-12, PATIR-13, PATIR-15, PATIR-61, PATIR-71, PATIR-81, PATIR-91 dan PATIR-101 dan disertakan 3 tanaman pembanding yaitu Zh-30 (induk) dan varietas Kawali serta Mandau (kontrol nasional). Pupuk yang digunakan adalah: urea, TSP-36 dan $\mathrm{KCl}$ dengan takaran berturut-turut 200, 150 dan $90 \mathrm{~kg} / \mathrm{ha}$, diberikan pada saat tanam kecuali pupuk urea yaitu 1/3 diberikan saat tanam dan $2 / 3$ bagian pada saat tanaman berumur satu bulan.

Kegiatan uji adaptasi dilakukan di 10 lokasi percobaan pada dua musim tanam yaitu 5 lokasi musim hujan (MH) 2011/2012 dan 5 musim kemarau (MK) 2012. Pengujian musim hujan dilakukan di lokasi Probolinggo-Jawa Timur, Boyolali-Jawa Tengah, Tanjung PinangKepulauan Riau, Citayam Bogor dan SubangJawa Barat. Pengujian pada musim kemarau dilakukan di lokasi Gunung Kidul-Yogyakarta, Boyolali-Jawa Tengah, Tanjung PinangKepulauan Riau, Citayam-Bogor dan SubangJawa Barat. Pada masing-masing lokasi pengujian, setiap materi tanaman ditanam dalam petakan (plot) berukuran $5 \times 4 \mathrm{~m}^{2}$, dan rancangan acak kelompok dengan 3 ulangan digunakan dalam pengujian di setiap lokasi. Produksi biji kering per hektar didapatkan dengan cara menghitung komponen hasil dari ukuran plot dibagi jumlah tanaman yang dipanen, dikalikan populasi per hektar [6], dengan rumus sebagai berikut: 
Produksi biji kering $(\mathrm{t} / \mathrm{ha})=\frac{\text { hasil (kg/plot) }}{\sum \text { tanaman dipanen/plot }} \times \frac{\sum \text { tanaman } / \mathrm{ha}}{\text { ha }} \times \frac{1 \text { ton }}{1000 \mathrm{~kg}}$

Data ANOVA dianalisa menggunakan software komputer metode SAS versi 9.1 dan diuji lanjut menggunakan uji BNT 5\% [7].

\section{HASIL DAN PEMBAHASAN}

Pengujian adaptasi multilokasi merupakan kegiatan akhir dari beberapa program pemuliaan tanaman. Setelah dilakukan seleksi, observasi dan pemurnian dilanjutkan uji daya hasil pendahuluan dan lanjutan telah diperoleh 10 galur mutan harapan. Galur-galur tersebut perlu dilakukan uji adaptasi guna untuk mengetahui tingkat produktivitas dan kemampuan dalam beradaptasi diberbagai lokasi daerah di Indonesia. Hal ini sebagai prasyarat jika akan diajukan dan dilepas menjadi varietas baru.

Tabel 1 pengujian pada tanam musim hujan (MH) terhadap produksi biji di 5 lokasi percobaan terlihat bahwa masing-masing lokasi seperti di Boyolali-Jawa Tengah dari 10 galur materi uji, memiliki kisaran produksi biji antara 5,07-7,00 t/ha sedangkan ketiga tanaman kontrol memiliki kisaran 4,90-6,23 t/ha. Hal ini memperlihatkan bahwa semua galur mempunyai produksi lebih tinggi dibandingkan ketiga tanaman kontrol kecuali galur PATIR-12 dan PATIR-13 hanya unggul dari varietas Mandau. Secara uji BNT 5\% semua galur berbeda nyata dari varietas Mandau dengan kata lain bahwa semua galur lebih unggul dari varietas Mandau (4,90 t/ha) kecuali galur PATIR 12 dan PATIR-13 masing-masing hanya berproduksi 5,07 dan 5,33 t/ha. Walaupun tidak berbeda nyata namun memiliki nilai nominal hasil biji lebih tinggi.

Lokasi Probolinggo-Jawa Timur semua galur mutan memiliki produksi biji tinggi yaitu kisaran antara 4,33-6,87 t/ha dibandingkan ketiga tanaman kontrol kecuali galur PATIR-61 yaitu

Tabel 1. Produksi biji uji adaptasi pada musim hujan (MH) di 5 lokasi percobaan 2011/2012

\begin{tabular}{|c|c|c|c|c|c|c|}
\hline \multirow{3}{*}{$\begin{array}{l}\text { Nama galur/ } \\
\text { varietas }\end{array}$} & \multirow{2}{*}{\multicolumn{5}{|c|}{ PRODUKSI BIJI }} & \multirow{3}{*}{$\begin{array}{c}\text { Rerata gabungar } \\
\mathrm{MH}(\mathrm{t} / \mathrm{ha})\end{array}$} \\
\hline & \multicolumn{2}{|c|}{ MH (2011/2012) } & & & & \\
\hline & $\begin{array}{l}\text { Boyolali- } \\
\text { Jateng } \\
\text { (t/ha) }\end{array}$ & $\begin{array}{c}\text { Probolinggo- } \\
\text { Jatim } \\
\text { (t/ha) }\end{array}$ & $\begin{array}{c}\text { Tanj.Pinang- } \\
\text { Kep. Riau } \\
\text { (t/ha), }\end{array}$ & $\begin{array}{l}\text { Citayam- } \\
\text { Bogor } \\
\text { (t/ha) }\end{array}$ & $\begin{array}{c}\text { Subang- } \\
\text { Jabar } \\
\text { (t/ha) }\end{array}$ & \\
\hline PATIR-1 & $6,72^{c}$ & $6,68^{d}$ & $6,40 \mathrm{bc}$ & $7,43^{c}$ & $5,33^{\mathrm{a}}$ & $6,51^{c}$ \\
\hline PATIR-4 & $6,67^{c}$ & $6,21^{\mathrm{d}}$ & $5,92^{c}$ & $8,55^{\mathrm{ac}}$ & $5,43^{\text {a }}$ & $6,56^{\mathrm{ac}}$ \\
\hline PATIR-12 & $5,33^{d}$ & $5,73^{\mathrm{d}}$ & $5,11^{\mathrm{d}}$ & $6,63^{\mathrm{d}}$ & $5,04^{\mathrm{a}}$ & $5,57^{\mathrm{d}}$ \\
\hline PATIR-13 & $5,07^{\mathrm{d}}$ & $6,37^{\mathrm{d}}$ & $5,88^{c}$ & $8,00^{\mathrm{c}}$ & $4,88^{\mathrm{d}}$ & $6,04^{c}$ \\
\hline PATIR-15 & $6,76^{c}$ & $5,59^{d}$ & $5,41^{\mathrm{d}}$ & $7,79^{\mathrm{c}}$ & $5,40^{\mathrm{a}}$ & $6,19^{c}$ \\
\hline PATIR-61 & $7,00^{\mathrm{c}}$ & $4,33^{\mathrm{d}}$ & $3,96^{\mathrm{d}}$ & $7,78^{c}$ & $5,21^{\mathrm{a}}$ & $5,66^{\mathrm{d}}$ \\
\hline PATIR-71 & $6,65^{c}$ & $5,79^{\mathrm{d}}$ & $4,85^{\mathrm{d}}$ & $8,33^{c}$ & $4,94^{\mathrm{d}}$ & $6,02^{c}$ \\
\hline PATIR-81 & $6,79^{c}$ & $5,84^{\mathrm{d}}$ & $4,44^{\mathrm{d}}$ & $5,62^{d}$ & $5,37^{\mathrm{a}}$ & $5,62^{d}$ \\
\hline PATIR-91 & $6,28^{c}$ & $6,43^{\mathrm{d}}$ & $5,91^{\mathrm{c}}$ & $5,94^{\mathrm{d}}$ & $5,65^{\mathrm{ac}}$ & $6,04^{c}$ \\
\hline PATIR-101 & $6,71^{c}$ & $6,87^{\mathrm{bc}}$ & $5,71^{\mathrm{c}}$ & $7,06^{\mathrm{ac}}$ & $7,09^{a b c}$ & $6,69^{\mathrm{ac}}$ \\
\hline Zh-30 (tetua)(a) & 6,23 & 5,55 & 5,27 & 7,07 & 4,26 & 5,68 \\
\hline Var. Kawali (b) & 6,15 & 5,34 & 4,66 & 7,40 & 5,84 & 5,88 \\
\hline Var. Mandau (c) & 4,90 & 5,33 & 4,22 & 5,68 & 4,74 & 4,97 \\
\hline $\begin{array}{l}\text { Rerata tiap } \\
\text { lokasi (t/ha) }\end{array}$ & 6,26 & 5,85 & 5,21 & 7,18 & 5,32 & 5,95 \\
\hline BNT 5\% & 1,18 & 1,44 & 1,37 & 1,43 & 0,75 & 0,86 \\
\hline KK \% & 11,15 & 14,60 & 15,60 & 11,81 & 8,37 & 11,36 \\
\hline
\end{tabular}

Keterangan:

$\mathrm{a}=$ Nyata lebih unggul dari Zh-30 (tetua) pada uji BNT 5\%

$\mathrm{b}=$ Nyata lebih unggul dari varietas Kawali (kontrol nasional) pada uji BNT 5\%

$\mathrm{c}=$ Nyata lebih unggul dari varietas Mandau (kontrol nasional kadar nira tinggi) pada uji BNT 5\%

$\mathrm{d}=$ Nyata kalah unggul dari Zh-30 (tetua), Varietas Kawali dan Mandau pada uji BNT 5\% 
berproduksi biji hanya 4,33 t/ha sedangkan tanaman kontrol Zh-30 (induk), Kawali dan varietas Mandau (kontrol nasional) berturut-turut memiliki hasil biji hanya 5,33 t/ha, 5,34 t/ha dan 5,55 t/ha. Secara uji BNT 5\% semua galur tidak berbeda nyata kecuali galur PATIR-101 $(6,87$ t/ha) berbeda nyata atau lebih unggul dari Kawali (5,34 t/ha) dan varietas Mandau (5,33 t/ha) disajikan pada Tabel 1.

Lokasi Tanjung Pinang-Kepulauan Riau semua galur mutan memiliki produksi biji kisaran antara 3,96-6,40 t/ha sedangkan ketiga tanaman kontrol Zh-30 (induk), varietas Kawali dan Mandau berturut-turut 4,22, 4,66 dan 5,27 t/ha. Galur produksi tertinggi diperlihatkan pada galur PATIR-1 yaitu 6,40 t/ha dan terendah pada galur PATIR-61 hanya 4,33 t/ha. Secara uji BNT 5\% galur PATIR-1 berbeda nyata dengan varietas Kawali (4,66 t/ha) dan Mandau (4,22 t/ha) serta tidak berbeda dengan tanaman induk $(5,27 \mathrm{t} / \mathrm{ha})$ disajikan pada Tabel 1 .

Lokasi Citayam-Bogor semua galur menghasilkan biji kisaran antara 5,62-8,55 t/ha dan ketiga tanaman kontrol memiliki kisaran 5,687,40 t/ha. Produksi biji tertinggi didapat pada galur PATIR-4 (8,55 t/ha) dan diikuti galur PATIR-101 (7,06 t/ha) sedangkan galur terendah terlihat pada galur PATIR-81 (5,62 t/ha). Secara uji BNT 5\% galur PATIR-4 dan PATIR-101 memperlihatkan produksi biji tertinggi dan berbeda nyata dengan induk serta varietas Mandau masing-masing menghasilkan biji 5,68 t/ha dan $7,07 \mathrm{t} / \mathrm{ha}$ dan tidak berbeda nyata dengan varietas Kawali (7,40 t/ha) disajikan pada Tabel 1.

Lokasi Subang-Jawa Barat semua galur menghasilkan biji kisaran antara 4,88-7,09 t/ha dan ketiga tanaman kontrol memiliki kisaran 4,975,88 t/ha. Produksi biji tertinggi didapat pada galur PATIR-101 (7,09 t/ha) sedangkan galur terendah terlihat pada galur PATIR-13 (4,88 t/ha). Secara uji BNT 5\% galur PATIR-101 memperlihatkan produksi biji tertinggi dan berbeda nyata dengan induk serta varietas Kawali dan Mandau berturut-turut menghasilkan biji hanya 4,26, 4,74 dan 5,84 t/ha disajikan pada Tabel 1.

Hasil rata-rata gabungan dari 5 lokasi tanam pada musim hujan (MH) terhadap hasil biji produksi tertinggi diperlihatkan pada galur PATIR-101 (6,69 t/ha) dan diikuti galur PATIR-4 $(6,56 \mathrm{t} / \mathrm{ha})$. Secara uji BNT 5\% kedua galur berbeda nyata dengan $\mathrm{Zh}-30$ (induk) dan varietas Mandau masing-masing memiliki hasil 4,97 dan
$5,68 \mathrm{t} / \mathrm{ha}$ serta tidak berbeda nyata dengan varietas Kawali $(5,88 \mathrm{t} / \mathrm{ha})$ dengan kata lain bahwa kedua galur tersebut unggul dengan induknya dan varietas Mandau serta kalah unggul varietas Kawali. Walaupun semua galur tidak berbeda nyata dengan ketiga tanaman kontrol, namun semua galur tersebut memiliki hasil biji nilai nominal rata-rata tinggi kecuali galur PATIR-12, PATIR-61 dan PATIR-81 yaitu berturut-turut menghasilkan 5,57, 5,62 dan 5,66 t/ha hanya unggul dari kontrol varietas Mandau (4,97 t/ha) disajikan pada Tabel 1. Hal ini membuktikan bahwa radiasi sinar gamma terhadap sorgum dapat menghasilkan biji yang bervariasi sehingga pemulia dapat memilih sesuaia tujuan pemulian tanaman dan atau yang dikehendaki. Hal senada dilaporkan oleh SHU dan SOBRIZAl [8, 9, 10] bahwa radiasi sinar gamma dapat memperbanyak keragaman genetik dan memperbaiki plasma nutfah yang ada.

Tabel 2 pengujian tanam pada musim kemarau (MK) terhadap produksi biji di lokasi percobaan Citayam-Bogor terlihat bahwa semua galur mutan memiliki kisaran hasil biji antara 5,18-8,83 t/ha. Produksi biji tertinggi diperlihatkan pada galur PATIR-4 memiliki produksi biji yaitu sebesar 8,83 t/ha diikuti galur PATIR-71 (7,85 t/ha) sedangkan produksi terendah pada galur PATIR-81 (5,18 t/ha). Secara uji BNT 5\% galur PATIR-4 dan PATIR-71 berbeda nyata dari ketiga tanaman kontrol berturut-turut menghasilkan biji 4,35, 6,04 dan 6,31 t/ha kecuali galur PATIR-71 tidak berbeda nyata dengan $\mathrm{Zh}-30(6,31 \mathrm{t} / \mathrm{ha})$ dengan kata lain bahwa galur PATIR-71 kalah unggul dengan induknya.

Lokasi Subang-Jawa Barat tanam pada musim kemarau semua galur menghasilkan biji kisaran antara 4,04-6,03 t/ha dan ketiga tanaman kontrol memiliki kisaran 3,08-5,19 t/ha. Produksi biji tertinggi didapat pada galur PATIR-4 $(6,03$ t/ha) sedangkan galur terendah terlihat pada galur PATIR-12 (4,04 t/ha). Secara uji BNT 5\% galur PATIR-4 tidak berbeda nyata Zh-30 (induk) yaitu 5,19 t/ha dan berbeda nyata varietas Kawali serta Mandau berturut-turut menghasilkan biji 3,08 dan 4,37 t/ha. Walaupun dilokasi tersebut galur mutan umumnya tidak berbeda nyata dan atau kalah unggu dengan ketiga tanaman kontrol namun secara nilai nominal hasil biji tinggi sperti terlihat pada galur PATIR-1, PATIR-4 dan PATIR-91 berturut-turut memiliki hasil biji 5,86, 5,90 dan 6,03 t/ha disajikan pada Tabel 2. 
Tabel 2. Produksi biji uji adaptasi pada musim kemarau (MK) di 5 lokasi percobaan 2012

\begin{tabular}{|c|c|c|c|c|c|c|}
\hline \multirow{3}{*}{$\begin{array}{l}\text { Nama galur/ } \\
\text { varietas }\end{array}$} & \multicolumn{5}{|c|}{ PRODUKSI BIJI } & \multirow{3}{*}{$\begin{array}{c}\text { Rerata MK } \\
\text { (t/ha) }\end{array}$} \\
\hline & \multicolumn{5}{|c|}{ MK (2012) } & \\
\hline & $\begin{array}{l}\text { Citayam- } \\
\text { Bogor } \\
\text { (t/ha) }\end{array}$ & $\begin{array}{l}\text { Subang- } \\
\text { Jabar } \\
\text { (t/ha) }\end{array}$ & $\begin{array}{c}\text { Probolinggo- } \\
\text { Jatim } \\
\text { (t/ha) }\end{array}$ & $\begin{array}{l}\text { G. Kidul- } \\
\text { Yogya } \\
\text { (t/ha) }\end{array}$ & $\begin{array}{c}\text { Tanj.Pinang- } \\
\text { Kep. Riau } \\
\text { (t/ha), }\end{array}$ & \\
\hline PATIR-1 & $7,57^{c}$ & $5,90^{c}$ & $5,62^{\mathrm{c}}$ & $4,40^{\mathrm{c}}$ & $5,47^{c}$ & $5,79^{\mathrm{bc}}$ \\
\hline PATIR-4 & $8,83^{a b c}$ & $6,03^{b c}$ & $6,63^{\mathrm{abc}}$ & $4,72^{\mathrm{c}}$ & $5,32^{c}$ & $6,31^{\mathrm{abc}}$ \\
\hline PATIR-12 & $6,62^{c}$ & $4,04^{\mathrm{d}}$ & $4,95^{\mathrm{c}}$ & $4,08^{\mathrm{d}}$ & $4,60^{\mathrm{c}}$ & $4,86^{\mathrm{c}}$ \\
\hline PATIR-13 & $5,75^{\mathrm{d}}$ & $4,60^{\mathrm{d}}$ & $4,51^{\mathrm{d}}$ & $4,80^{\mathrm{bc}}$ & $4,55^{\mathrm{d}}$ & $4,84^{\mathrm{c}}$ \\
\hline PATIR-15 & $6,54^{c}$ & $4,31^{\mathrm{d}}$ & $5,39^{c}$ & $4,40^{\mathrm{c}}$ & $4,90^{\mathrm{c}}$ & $5,11^{\mathrm{c}}$ \\
\hline PATIR-61 & $7,22^{\mathrm{c}}$ & $4,76^{\mathrm{c}}$ & $3,42^{\mathrm{d}}$ & $2,95^{\mathrm{d}}$ & $4,60^{\mathrm{d}}$ & $4,59^{\mathrm{c}}$ \\
\hline PATIR-71 & $7,85^{b c}$ & $4,85^{\mathrm{c}}$ & $5,67^{\text {bc }}$ & $3,81^{\mathrm{d}}$ & $4,37^{\mathrm{d}}$ & $5,31^{\mathrm{c}}$ \\
\hline PATIR-81 & $5,18^{\mathrm{d}}$ & $5,00^{c}$ & $5,48^{\mathrm{c}}$ & $3,41^{\mathrm{d}}$ & $4,28^{\mathrm{d}}$ & $4,67^{\mathrm{c}}$ \\
\hline PATIR-91 & $7,16^{\mathrm{c}}$ & $5,86^{\mathrm{c}}$ & $5,42^{\mathrm{c}}$ & $4,48^{\mathrm{c}}$ & $5,70^{\mathrm{c}}$ & $5,72^{\mathrm{bc}}$ \\
\hline PATIR-101 & $5,67^{d}$ & $4,99^{\mathrm{c}}$ & $5,36^{\mathrm{c}}$ & $4,67^{\mathrm{c}}$ & $4,62^{\mathrm{d}}$ & $5,06^{\mathrm{c}}$ \\
\hline Zh-30 (tetua) (a) & 6,31 & 5,19 & 5,06 & 4,26 & 5,05 & 5,17 \\
\hline Var. Kawali (b) & 6,04 & 4,37 & 4,75 & 3,62 & 4,40 & 4,64 \\
\hline Var. Mandau (c) & 4,35 & 3,08 & 3,92 & 3,24 & 3,18 & 3,55 \\
\hline $\begin{array}{l}\text { Rerata tiap lokasi } \\
\text { (t/ha) }\end{array}$ & 6,55 & 4,84 & 5,09 & 4,07 & 4,69 & 5,05 \\
\hline BNT 5\% & 1,71 & 1,57 & 0,91 & 1,12 & 1,56 & 0,71 \\
\hline KK \% & 15,46 & 19,21 & 10,64 & 16,37 & 19,67 & 11,07 \\
\hline
\end{tabular}

Keterangan:

$\mathrm{a}=$ Nyata lebih unggul dari Zh-30 (tetua) pada uji BNT 5\%

$\mathrm{b}=$ Nyata lebih unggul dari varietas Kawali (kontrol nasional) pada uji BNT 5\%

$\mathrm{c}=$ Nyata lebih unggul dari varietas Mandau (kontrol nasional kadar nira tinggi) pada uji BNT 5\%

$\mathrm{d}=$ Nyata kalah unggul dari Zh-30 (tetua), Varietas Kawali dan Mandau pada uji BNT 5\%

Lokasi Probolinggo-Jawa Timur tanam pada musim kemarau semua galur mutan memiliki produksi biji kisaran antara 4,51-6,63 t/ha dan ketiga tanaman kontrol kisaran antara 3,92-5,06 t/ha. Produksi biji tertinggi dicapai pada nomor galur PATIR-4 (6,63 t/ha) diikuti galur PATIR-71 $(5,67 \mathrm{t} / \mathrm{ha})$ sedangkan galur terendah pada nomor PATIR-61 (3,42 t/ha). Secara uji BNT 5\% galur mutan PATIR-4 berbeda nyata dari ketiga tanaman kontrol, sedangkan galur PATIR-71 tidak berbeda nyata dengan induk $(5,06 \mathrm{t} / \mathrm{ha})$ dan berbeda nyata dengan kontrol nasional Kawali dan varietas Mandau masing-masing memiliki hasil biji 3,92 dan 4,75 t/ha disajikan pada Tabel 2 .

Lokasi di Gunungkidul-Yogyakarta semua galur mutan memiliki produksi biji yaitu kisaran antara 2,95-4,80 t/ha dan ketiga tanaman kontrol memiliki kisaran 3,24-4,26 t/ha. Galur produksi tertinggi diperlihatkan pada galur nomor PATIR$13(4,80 \mathrm{t} / \mathrm{ha})$ dan terendah pada galur PATIR-61 (2,95 t/ha). Secara uji BNT 5\% galur PATIR-13 $(4,80 \mathrm{t} / \mathrm{ha})$ tidak berbeda nyata dengan induk $(4,26$ t/ha) dan berbeda varietas Kawali dan Mandau masing-masing (3,24 dan 3,62 t/ha) disajikan pada Tabel 2.

Lokasi Tanjung Pinang-Kepulauan Riau semua galur mutan memiliki produksi biji kisaran antara 4,28-5,70 t/ha sedangkan ketiga tanaman kontrol memiliki kisaran hasil antara 3,18-5,05 t/ha. Galur produksi tertinggi diperlihatkan pada galur PATIR-91 (5,70 t/ha) dan terendah pada galur PATIR-81 hanya 4,28 t/ha. Secara uji BNT $5 \%$ semua galur tidak berbeda nyata dengan induk (5,05 t/ha) dan kontrol varietas Kawali (4,40 t/ha) disajikan pada Tabel 2.

Hasil tanam musim kemarau (MK) ratarata gabungan dari 5 lokasi terhadap produksi biji, bahwa galur PATIR-4 terlihat memiliki hasil biji tertinggi diikuti galur PATIR-1 dan PATIR-91 berturut-turut memiliki hasil biji 6,31, 5,79 dan 5,72 t/ha. Sacara uji BNT 5\% galur PATIR-4 berbeda nyata dari ketiga tanaman kontrol dan galur PATIR-1 dan PATIR-91 tidak berbeda nyata dari Zh-30 memiliki hasil 5,17 t/ha dan berbeda nyata dengan varietas Kawali dan Mandau hanya menghasilkan biji 3,55 dan 4,64 t/ha disajikan pada Tabel 2. Meskipun beberapa galur mutan ada 
yang memiliki hasil rendah namun penelitian tersebut masih melampaui hasil percobaan ROESMARKAM, S. [11], yang dilakukan pada tahun 1987 di Citayam dan Muara, Bogor, memperbaiki beberapa sifat tanaman seperti diantaranya pada biji. Adanya galur-galur mutan yang memiliki produksi biji tinggi diharapkan dapat dimanfaatkan berbagai stake holders

Tabel 3. Ranking rata-rata gabungan produksi biji dari 10 lokasi percobaan pada musim tanam $\mathrm{MH}$ dan MK

\begin{tabular}{|c|c|c|c|c|}
\hline \multirow[t]{2}{*}{ Nama galur/varietas } & \multicolumn{2}{|c|}{$\begin{array}{l}\text { Produksi biji } \\
\text { (t/ha) }\end{array}$} & \multirow{2}{*}{$\underset{(\mathrm{t} / \mathrm{ha})}{\text { Rerata }}$} & \multirow[t]{2}{*}{ Ranking } \\
\hline & MH & MK & & \\
\hline PATIR-1 & $6,51^{\mathrm{c}}$ & $5,79^{\mathrm{ab}}$ & $6,15^{\mathrm{abc}}$ & 2 \\
\hline PATIR-4 & $6,54^{\mathrm{ac}}$ & $6,31^{a b c}$ & $6,43^{\mathrm{abc}}$ & 1 \\
\hline PATIR-12 & $5,57^{\mathrm{d}}$ & $4,86^{\mathrm{c}}$ & $5,21^{\mathrm{c}}$ & 10 \\
\hline PATIR-13 & $6,04^{\mathrm{c}}$ & $4,84^{\mathrm{c}}$ & $5,44^{\mathrm{c}}$ & 7 \\
\hline PATIR-15 & $6,19^{\mathrm{c}}$ & $5,11^{\mathrm{c}}$ & $5,65^{\mathrm{c}}$ & 6 \\
\hline PATIR-61 & $5,66^{\mathrm{d}}$ & $4,59^{\mathrm{c}}$ & $5,12^{\mathrm{c}}$ & 12 \\
\hline PATIR-71 & $6,11^{\mathrm{c}}$ & $5,31^{\mathrm{c}}$ & $5,67^{\mathrm{c}}$ & 5 \\
\hline PATIR-81 & $5,61^{\mathrm{d}}$ & $4,67^{\mathrm{c}}$ & $5,14^{\mathrm{c}}$ & 11 \\
\hline PATIR-91 & $6,04^{\mathrm{c}}$ & $5,72^{\mathrm{bc}}$ & $5,88^{\mathrm{bc}}$ & 3 \\
\hline PATIR-101 & $6,69^{\mathrm{ac}}$ & $5,06^{\mathrm{c}}$ & $5,88^{\mathrm{bc}}$ & 4 \\
\hline Zh-30 (tetua) (a) & 5,68 & 5,17 & 5,43 & 8 \\
\hline Var. Kawali (b) & 5,88 & 4,64 & 5,26 & 9 \\
\hline Var. Mandau (c) & 4,97 & 3,55 & 4,26 & 13 \\
\hline Rerata (t/ha) & 5,95 & 5,05 & 5,50 & \\
\hline BNT 5\% & 0,86 & 0,71 & 0,55 & \\
\hline KK \% & 11,15 & 11,07 & 11,36 & \\
\hline
\end{tabular}

Keterangan:

$\mathrm{a}=$ Nyata lebih unggul dari Zh-30 (tetua) pada uji BNT 5\%

$\mathrm{b}=$ Nyata lebih unggul dari varietas Kawali (kontrol nasional) pada uji BNT 5\%

$\mathrm{c}=$ Nyata lebih unggul dari varietas Mandau (kontrol nasional kadar nira tinggi) pada uji BNT 5\%

$\mathrm{d}=$ Nyata kalah unggul dari Zh-30 (tetua), Varietas Kawali dan Mandau pada uji BNT 5\%

menghasilkan rata-rata produksi biji kering hanya $5 \mathrm{t} / \mathrm{ha}$.

Tabel 3 berdasarkan hasil rata-rata analisis gabungan dari 10 lokasi pada tanam musim hujan dan kemarau terlihat bahwa galur PATIR-4 menduduki ranking pertama yaitu memiliki produktivitas rata-rata biji sebesar 6.43 t/ha, diikuti galur PATIR-1 memiliki produktivitas biji $6.15 \mathrm{t} / \mathrm{ha}$. Angka ini berbeda nyata dengan hasil tanaman kontrol yaitu Zh-30 (induk) 5.43 t/ha dan varietas Kawali serta varietas Mandau (kontrol nasional) masing-masing hanya 4.26 dan $5.26 \mathrm{t} / \mathrm{ha}$. Dengan kata lain bahwa sorgum dengan perlakuan radiasi sinar gamma dosis 300 Gy telah memperoleh galur mutan PATIR-1 dan PATIR-4 yang memiliki sifat produksi biji lebih baik dengan induknya. Hal ini senada dilaporkan oleh ARWIN et al [12] bahwa pemuliaan tanaman menggunakan radiasi sinar gamma dapat termasuk petani serta pengguna lainnya sehingga akan mendukung kedaulatan dan ketahanan pangan di Indonesia.

\section{KESIMPULAN}

Pemuliaan mutasi menggunakan radiasi sinar gamma pada dosis 300 Gy memperbaiki dan meningkatkan hasil biji sorgum.

Galur mutan PATIR-1 dan PATIR-4 ditanam pada musim hujan dan kemarau memiliki produksi biji tinggi dan beda nyata lebih unggul dibandingkan induknya dan kedua tanaman kontrol yaitu varietas Kawali dan Mandau. 


\section{UCAPAN TERIMA KASIH}

Ucapan terimakasih kami sampaikan kepada dinas BPSB Pusat maupun Daerah dan pihak lain yang telah membantu terlibat dalam uji adaptasi galur-galur mutan sorgum.

\section{DAFTAR PUSTAKA}

1. House, Lr., A Guide to Sorghum Breeding. International Crops Research Institute for Semi-Arid Tropics. Andhra Pradesh, India., pp. 238,. 1995.

2. Soeranto, H., Sihono dan Parno. Perbaikan genetik sorgum melalui program pemuliaan tanaman. Makalah dalam Fukus Grup Diskusi "Prospek Sorgum untuk Mendukung Ketahanan Pangan dan Energi". MENRISTEK-BATAN. Serpong. pp. 15-31, 2006.

3. BATAN. Hasil Teknologi Batan di Bidang Pertanian.

http://www/batan/pair/_pert/pert.html.

(Di akses tanggal 10 Juni 2017).

4. Soeranto. H dan Nakanishi, Tm., Mutation breeding in sorghum in Indonesia. Radioisotope Journal, Vol.50, No.5. Japan Radioisotope Association. Pp. 1$16,2001$.

5. Sihono. Penampilan Sifat Agoromi Galur Mutan Sorgum (Sorghum bicolor L. Moench) di Kabupaten Bogor. J. Ilm. Apl. Isot. dan Radiasi, vol. 5, no. 1, pp. 31-42, 2009.

6. Sihono, Wijaya, M., Indriatama dan Soeranto H. Evaluasi Daya Hasil Galur Mutan
Harapan Sorgum Manis (Sweet Sorghum) pada Musim Hujan. Prosiding Seminar Nasional Perhimpunan Ilmu Pemuliaan Indonesia PERIPI. Bogor. pp. 310-319, 2013.

7. Sihono, Soeranto Human, Wijaya M, Indriatama, Carkum, Parno dan Winda Puspitasari. Proposal Pelepasan Varietas "Galur Mutan Sorgum PATIR-1 Berdaya Hasil Biji, Biomassa dan Gula Batang Tinggi serta Galur Mutan PATIR-4 Hasil Biji Tinggi Kualitas Baik”. Jakarta. pp. 1-112, 2014.

8. Shu, Q.Y., Bp.Forsten and H.Nakagawa. Plant Mutation Breeding and Biotechnology. IAEA Training, Jakarta Indonesia. pp. 1-41, 2012.

9. Sobrizal. Potensi Pemuliaan Mutasi untuk Perbaikan Varietas Padi Lokal Indonesia. J. Ilm. Apl. Isot. dan Radiasi, vol. 12, no. 1, pp. 23-35, 2016.

10. Sobrizal. Mutasi Induksi untuk Mereduksi Tinggi Tanaman Padi Galur KI 237. J. Ilm. Apl. Isot. dan Radiasi, vol. 4, no. 2, pp. 99-108, 2008.

11. Roesmarkam, S. Stabilitas hasil Tinggi dan Umur Tanaman Galur-galur Harapan Sorgum. Kumpulan Kliping Sorgum. Pusat Informasi. Pertanian Trubus. pp. 44-49, 1988.

12. Arwin, Hary Is Mulyana, Tarmizi, Masrizal, Khavid Faozi dan Mukhlis Adie. Galur Mutan Kedelai Super Genjah Q-298 dan 4-Psj. J. Ilm. Apl. Isot. dan Radiasi, vol. 8, no. 2, pp. 107-116, 2012. 
Jurnal Ilmiah Aplikasi Isotop dan Radiasi

A Scientific Journal for The Applications of Isotopes and Radiation

p ISSN 1907-0322

Vol. 13 No. 1 Juni 2017

e ISSN 2527-6433 